\title{
RESEARCH OF CONSUMERS' ATTITUDES ON THE ORGANIC FOOD CONSUMPTION IN THE SERBIAN ENCLAVES IN KOSOVO
}

\author{
Goran Maksimović ${ }^{1}$, Božidar Milošević ${ }^{2}$ Radomir Jovanovićc ${ }^{3}$
}

\begin{abstract}
The organic production in Serbian enclaves in Kosovo has a great potential based on the extensive production mostly in hilly-mountainous areas with rich and convenient environment for the organic production of medicinal plants, fruits, vegetables, wine, honey etc., but it still keeps developing. The enclave can realise a high income, and thereby also an economic basis for the sustainable development of multifunctional agricultural holdings in Serbian enclaves, by the production and sale of organic products on local markets. In this paper, the authors study the consumers'attitudes on purchase and consumption of organic food in Serbian enclaves in Kosovo. Empirical research was carried out on a spatial sample of 300 respondents, by a personal communication technique using the questionnaire as an instrument of research method. Areas of research are towns: Northern KosovskaMitrovica, Leposavic, ZubinPotok and Gracanica. Goal of the research is to discover the preferences, motives, attitudes and interests of consumers for buying the organic products, based on a defined survey to recognise the basic features of supply and the demand of organic agricultural and food products. After analysing the conducted survey, we have discovered that the organic food market in Serbian enclaves in Kosovo has not been sufficiently developed; it is necessary to expand the range of organic agriculture products and a constant supply is required, better marketing, and better information and education of consumers in order to raise supply to a higher level.
\end{abstract}

Key words: organic agriculture, organic food consumption.

JEL:Q13, E31, D12

1 Goran Maksimović Ph.D., Associate Professor, University Of Priština, Faculty of Agriculture, Kopaoničkastreet nn, 38219 Lešak, Serbia, Phone: +381 63 419 757, E-mail: goran.maksimovic@pr.ac.rs

2 Božidar Milošević Ph.D., Full Professor, University Of Priština, Faculty of Agriculture, Kopaonička street nn, 38219, Lešak, Serbia, Phone: +381 64150 5273, E-mail: bozidar.milosevic@pr.ac.rs

3 Radomir Jovanović Ph.D., Assistant Professor, University Of Priština, Faculty of Agriculture, Kopaonička street nn, 38219, Lešak, Serbia, Phone: +381 65561 3940, E-mail: radomir.jovanovic@pr.ac.rs

EP 2017 (64) 3 (987-1001) 


\section{Introduction}

According to FAO (United Nations Organization for Agriculture) and WHO (World Health Organization) definition, the organic production is a system of production management, which promotes the preservation of eco-system by unifying biodiversity, biological cycles with emphasis on a need of methods that exclude the use of inputs for production outside a farm. The organic agricultural production is highlighting the quality and safety avoiding the application of synthetic mineral fertilizers, plant protection agents, growth regulator in livestock breeding and additives for animal feed. The organic production provides a harmonic management of nutrients, and the result is a tasty, healthy-safe organic product of high nutritional value, rich with macro and micro elements and vitamins as well. Hereof a regular consumption of organic products contributes to the preservation and improvement of health and preventing the occurrence of diseases. Organic product is the result of organic production that realises along with the application of agro-technical measures, which eliminate the use of synthetic-chemical agents. The main goal of organic agriculture is the production of high nutritional value food, development of sustainable agriculture along with the eco-system preservation, maintenance and increase of soil fertility, the use of landfill and stable manure or plants of long root in a permanent crop rotation and adding composted dung in soil. It implies maximum use of renewable sources of energy, preservation of agro-ecosystem genetic diversity and the environmental protection, reduction of all kinds of pollution that may be the consequence of agricultural production in order to create the conditions for satisfying the basic life needs of farmers, and gaining some profit (Radoičić,A. 2013) Organic manufacturers manage with 43.7 million hectares. The global organic food market in the year 2014 was achieved the value of 80 milliard USD, while the leading role has USA, Germany, France and China. There were 260000 organic manufacturers in EU in 2014 and about 340000 organic manufacturers in the whole Europe (Meredith and Willer, 2016). The organic food market in European countries and in the world records fast growth; however, it is still under developed in our country. Total areas under the organic production in the Republic of Serbia stretch on area of 15,298.02 ha (Ministry of Agriculture and Environmental Protection, 2016). Total turnover of the organic food sector amounts around 40 million USD. As Willer and Lemoud stated (2016), our country significantly lags behind in comparison with other European countries, with an average expenditure per capita of 5 USD. According to the previous research results, it is obvious that the consumption of organic food per capita in Serbia was significantly lower in comparison to consumption in European countries (Meredith and Willer, 2016; Golijan and Popović, 2016). Reasons for such bad condition in the organic food consumption in Serbia, according to Vehapi (2015) were insufficient information of consumers, poor and monotonous supply of organic food products, poorly developed distribution channels and low personal income of population. 


\section{Working material and a method of work}

In this paper, the authors study the consumers' attitudes on purchase and consumption of organic food in Serbian enclaves in Kosovo. Empirical research was carried out on a simple sample of 300 respondents, by a personal communication technique, field research, using a survey as an instrument of test method. Test areas are towns: Northern KosovskaMitrovica, Leposavic, ZubinPotok and Gracanica. The research goal is to perceive main features of demand and consumption of the organic agricultural and food products based on the defined survey. The research was done in May and June 2017, and the survey was lasting for 30 days. When designing the survey, there was used the quantitative approach in order to get data on who, in which extent and where buys the organic food, and the quality approach in order to determine the motive for purchasing the organic products. Advantage of the survey reflects in a fact that it can comprise wide area of the respondents; there avoids the influence of an examiner (interviewer) on the respondents' answers -Vlahović B. (2011). The questionnaire is composed of 26 questions and divided into two parts; the first part refers to general questions: gender, place of living, level of education, and the respondents' income. The second part of the questionnaire was done in order to discover preferences, motives, attitudes and interests of consumers for the purchase of organic products. The survey results are expressed in tables and charts.

\section{Research results}

In the respondents' structure, according to gender, the female population is more represented $(60 \%)$, while the male population is represented with $40 \%$. The survey was conductedin towns: Northern KosovskaMitrovica, Leposavic, ZubinPotok and Gracanica, and therefore the survey results show that $51.50 \%$ respondents live in urban areas, while $48.50 \%$ respondents live in rural or suburban settlements. We have discovered, by analysing the age category of respondents, that the survey has comprised persons older than eighteen years and persons who have their own incomes and the attitude on the organic food significance. The most of respondents is $18-25$ years of age (34.50\%), and then the respondents of 26-35 years of age (28.50\%), 36-45 years of age $(15.50 \%), 46-55$ years of age $(9.50 \%)$ and finally the respondents over 55 years of age $(12 \%)$. The most of respondents have secondary education (36\%), while $26 \%$ of respondents have college education, and $22 \%$ of respondents have university education, and the least respondents have only elementary education (16\%). One third of respondents (33\%) have a monthly income in the range from 40,000 to 60,000 RSD, $31.50 \%$ of respondents have a monthly income over 60,000 RSD, while $22 \%$ of respondents have a monthly income in the range from 20,000 to 40,000 RSD, and the lowest incomes (up to $20,000 \mathrm{RSD}$ ) have $13.50 \%$ of respondents. 
Table 1. General questions in the survey

\begin{tabular}{|c|c|c|c|}
\hline & Respondents & $\%$ & \\
\hline \multirow[b]{2}{*}{ Gender } & Male & 120 & $40 \%$ \\
\hline & Female & 180 & $60 \%$ \\
\hline \multirow[b]{2}{*}{ Place of living } & Town & 155 & $51.5 \%$ \\
\hline & Village & 145 & $49.5 \%$ \\
\hline \multirow{5}{*}{ Age } & Up to 25 & 103 & $34.5 \%$ \\
\hline & $26-35$ & 85 & $28.5 \%$ \\
\hline & $36-45$ & 47 & $15.5 \%$ \\
\hline & $46-55$ & 29 & $9.5 \%$ \\
\hline & Over 55 & 36 & $12 \%$ \\
\hline \multirow{4}{*}{ Education } & Elementary school & 48 & $16 \%$ \\
\hline & Secondary school & 108 & $36 \%$ \\
\hline & College education & 78 & $26 \%$ \\
\hline & University education & 66 & $22 \%$ \\
\hline \multirow{4}{*}{$\begin{array}{c}\text { Total } \\
\text { monthly income }\end{array}$} & Up to 20,000 & 41 & $13.50 \%$ \\
\hline & $20,000-40,000$ & 66 & $22.00 \%$ \\
\hline & $40,000-60,000$ & 99 & $33.00 \%$ \\
\hline & \begin{tabular}{|l|} 
Over 60,000 \\
\end{tabular} & 94 & $31.50 \%$ \\
\hline
\end{tabular}

Source: Authors's research

The research results show that the most of interviewed respondents (72\%) of different sex and age structure and different purchasing power feed in a classic (conventional) way, i.e. in most of cases those are cooked meals; this is expected since this is the area with traditional habits concerning diet. Most of the week $14.50 \%$ of interviewed respondents consumes fast food and this population is younger than 35 years. Some other form of diet is consumed by $7 \%$ of respondents; a small number of respondents $(3.5 \%)$ are vegetarians, while $3 \%$ of respondents in Serbian enclaves in Kosovo consume macrobiotic food. The obtained answer to the issue about information on the organic food production was positive by all respondents $(100 \%)$ which mean that they are informed about the organic production. This problem was studied by Vlahovicand associates (2010) and was concluded that $89 \%$ of respondents in Novi Sad was informed about the organic agricultural production, while $11 \%$ of respondents wasn't informed. People older than 65 years of age $(33 \%)$ and the respondents with the lowest education (45\%) show the ignorance of these products. According to Renko and Bosnjak research (2009) $83 \%$ of respondents in Croatia have heard for organic products. That is a little less in regard tothe survey results, which was conducted in Novi Sad, and the conclusion was that there was progress in consumers' information and was a good precondition for the development of organic agricultural production and purchase of organic products. 
Chart 1. Information on organic production (\%)

\section{They are $100 \%$ informed}

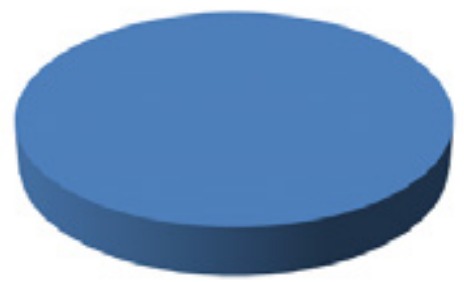

Source: Authors's research

Chart 2. Respondents' diet (\%)

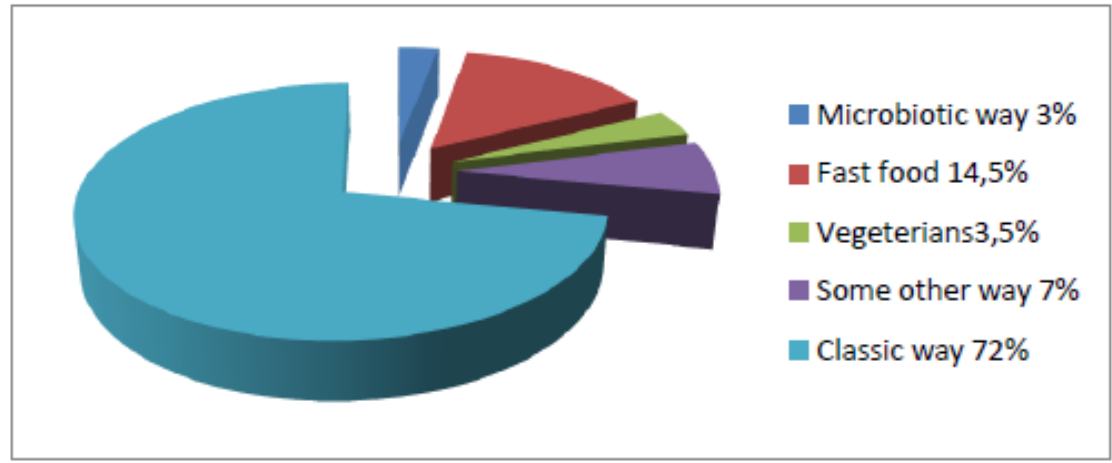

Source: Authors's research

The survey shows that $70 \%$ of respondents buy organic food (at least once a week $23.50 \%$, always buy the specific type of organic products $23.50 \%$, once a month $15 \%$ and once in three months $8 \%$ ), while $30 \%$ of respondents don't buy organic food. This ratio of the obtained answers is surely not satisfying, but is relatively encouraging since the organic food market in our country is still in inception, so as such it bears a serious of negative epithets: small, underdeveloped, poorly supplied, with poor range of products and high cost price. If we cross the obtained answers with the age structure of respondents, we notice that there is no significant correlation link. It means that the respondents from different age categories don't have the defined frequency in purchasing organic food. In the group of respondents who buy the organic products the most are surely those with the highest income (over 60,000 RSD) or $29.50 \%$, the respondents with income up to 60,000 RSD $(27.50 \%)$, then the respondents up to 40,000 RSD (11\%) and only $2 \%$ of respondents with incomes up to 20,000 RSD. From everything previously stated, we can conclude that the demand for organic products substantially depends on the amount of monthly incomes and the increase of demand can be expected with the growth of standard of living. But also all population categories need to buy food manufactured by the organic principles. 
Chart 3. Purchase of organic products (\%). Chart 4: Frequency of the organic products purchase $(\%)$

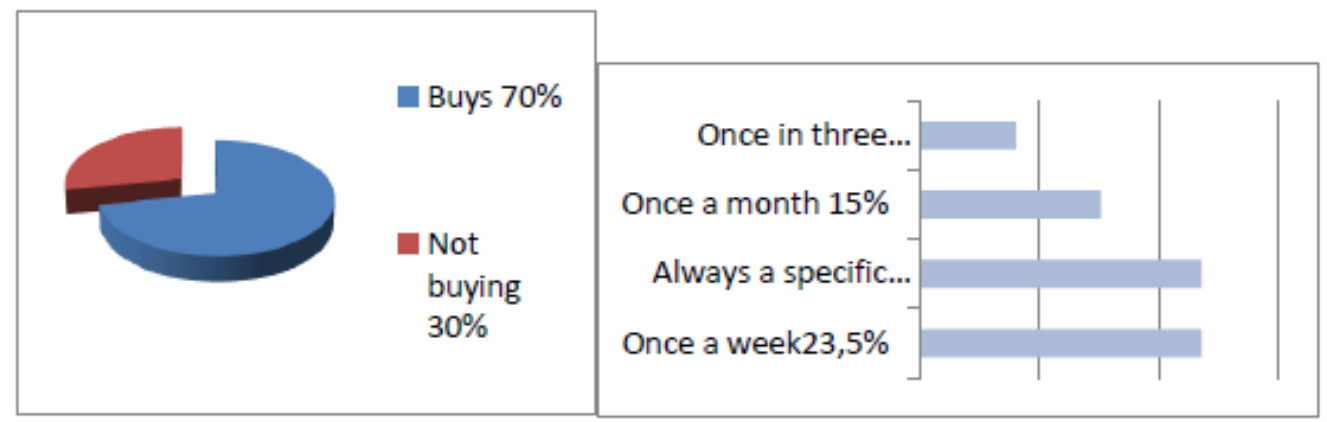

Source: Authors's research

Source: Authors's research

As the answer to the question where the organic products should sell, there were respondents who made the combination of two and more answers and the answers were relatively homogenous: supermarkets were in the first place with $21.5 \%$, green markets $21 \%$, small shops in the vicinity $20.5 \%$, and in the fourth place were directly from manufacturers $16 \%$, in some other way $11 \%$ of respondents, and in health food stores $10 \%$ of respondents.In the structure of total sale of organic agro-food products in the European Union, the highest share in supply (at the level of 31\%)hasthegeneral type retail chains. The following sales channels are markets with the share of $22 \%$, and there is also significant the share of specialized health food stores $(18 \%)$. In the European Union, the consumers of agro-food products (14\%) buy them directly from manufacturers, while $15 \%$ of organic food is sold via some other sales channels (Vlahović, Puškarić, 2013).

Chart 4. Place of the organic food supply

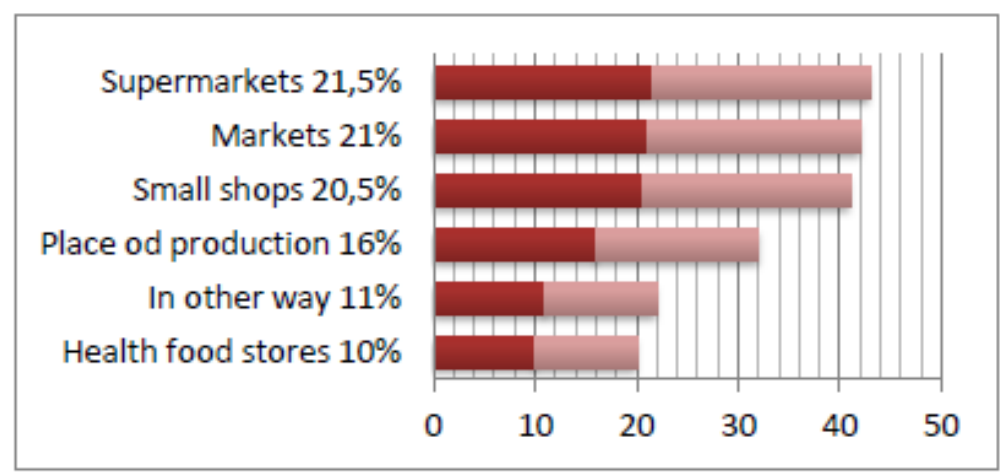

Source: Authors's research

With the following question in the survey "What would affect your decision to buy organic food?", we discovered the main motives to purchase the organic products. In the first place was the answer that the organic products were healthier for diet $(50 \%)$; $38.5 \%$ of respondents were stated that quality was the most important. Only $4.5 \%$ of 
respondents replied that trends in the world are the reason to purchase the organic products, and $4.5 \%$ of respondents consider some other motives (curiosity, higher nutritional value, and nutritional supplements) are decisive for purchasing the organic food, while only $2.5 \%$ of respondents considers the environment preservation as a crucial factor for making decision on buying the organic food.Series of consumers' research in the world have discovered that health was the primary motive to buy the organic food, while others, less important factors of motivation referring to the same food category were curiosity, the desire to help in the preservation of the environment, additional nutrition (nutritional supplements/higher nutritional value) and taste (Chakrabarti, Baisya, 2007). According to the research of Chambers and associates (2008), they were discovered that health is an important factor of which depended the total food consumption, especially concerning older people when they opt for a daily diet, while on the other side, they quoted a price as the possible obstacle for purchasing healthy food. Similar to that, according to the obtained results in pan-European research, Lappalainen and his associates (1997) stated the lack of time and price of food as some of the main obstacles for healthy nutrition.

Regarding the asked question on the structure of (potential) purchase of organic products, the authors of the paper and survey discovered which products are most purchased or should be purchased in the field of organic food by the respondents. Several answers were given to this question, so there were the respondents who buy or would buy more than one product. The most of respondents $(60.5 \%)$ were answered that they would buy all organic products (vegetables, fruits, meat, eggs and milk) according to their purchasing power; $16.5 \%$ of respondents would preferably buy organic vegetables; $12 \%$ of respondents buy or would buy only organic fruits. Meat, as an organic product, would buy or buy $5.5 \%$ of respondents, while only $3 \%$ of respondents were interested in purchasing the organic eggs, and $2.5 \%$ of respondents were interested in purchasing the organic milk. If we compare these results with foreign researches, the survey analysis (Briz and Al-Hajj, 2004) was shown that Spanish consumers mostly purchase fresh fruits and vegetables (77\%). At the same time, the research results of Eves and associates (2004) in Great Britain pointed out that the biggest demand was for fresh vegetables $(40 \%)$. The issue of domestic organic food market supply was raised in order to perceive the attitudes of the survey participants on the domestic market supply with organic products. Most of respondents $(68.5 \%)$ consider that the supply of the market is neither sufficient nor good, and $27.5 \%$ of respondents consider it sufficient for our conditions, and only $4 \%$ think that the market supply with organic products is completely satisfying. The results of previous studies are similar to the survey results. In the survey was raised an issue on the reasons for not consuming the organic products, aiming to recognize the reasons for not buying and not consuming the organic products. All respondents (those who purchase and don't purchase the organic products) answered this question; the most of respondents (38\%) answered that they buy the organic food but not as much as they would like to, for which they mentioned the next reasons: high prices, poor purchasing power and poor supply. Insufficient 
supply of the market with organic products is the reason for the lower consumption of organic products $(24 \%)$. Some of the respondents $(22.5 \%)$ have stated high prices as the most significant factor for not buying the organic products as much as they would like to. Some of the respondents $(8.5 \%)$ stated that the consumption could be increased if advertising and marketing of organic products are better, and $6.5 \%$ of respondents don't have confidence in the organic origin of products, while $0.5 \%$ of respondents gave some other reasons for not purchasing the organic products.

Chart 5. Reasons for not consuming the organic products (\%)

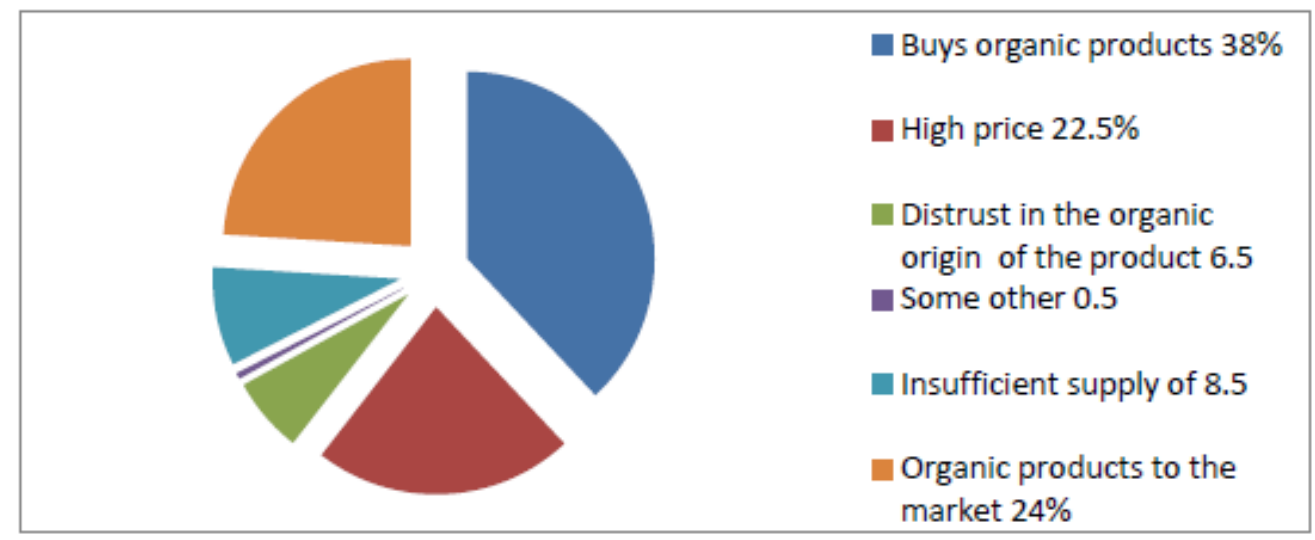

Source: Authors's research

The authors concluded, according to the obtained answers, that a price is the most important factor that affects the purchase and consumption of organic products; by the growth of employment and surpassing the economic crisis, the increase in the organic production volume and higher competitiveness will affect the decrease of prices and the increase in the organic products demand.

The surveyed respondents recognize an organic product in $35 \%$ cases by its mark "organic", $32 \%$ of respondents by a mark "bio", and $28 \%$ of respondents recognize an organic product by its mark "eco", and the least of respondents (5\%) don't pay attention to the organic product marks. Aiming to achieve better information and introduction of consumers with labelling and marks of the organic products,it is necessary to promote them as much as possible and bring closer to consumers by using all marketing elements, and especially advertising. Thereby shouldn't be forgotten that many countries before us have passed all these phases, and that we can rely on their experiences in order to pass as faster as possible the first and the most important phase of the population education and in that way give Serbia a chance to join the most developed European countries and their standards (Radoičić 2013).Furthermore, we have concluded, by analysing the answers to the question about the level of trust in the guarantee of organic products, that $79 \%$ of respondents is not sure if the mark for "organic"is at the same time the guarantee that this product is of the organic origin, $12 \%$ of respondents think that the mark is not the guarantee, while only $9 \%$ of respondents think that the mark is the guarantee that this product is really organically manufactured.These survey results show the necessity to inform better, by which affects the increase in the level of trust in marks and 
labels, as the guarantee of organic origin.

Aerset and associates (2004) proved that the distrust in the organic production certificate is common in many countries and it had the negative effects in the organic production. According to the research results of Kovacic and associates (2009) related to Zagreb, only $29 \%$ of respondents trusted eco-labels, while $26 \%$ of respondents didn't trust them. Significant number of respondents $(30 \%)$ trusts only the specific labels, but they don't know exactly to which ones they trust. This is surely greater trust in regard to the survey carried out in the Serbian enclaves in Kosovo and Metohija.

To the question - on what basis you decide which food is manufactured in a healthy-safe way $46 \%$ of respondents answered that it was according to an appropriate mark on a product, $35 \%$ answered that it was according to visual experience or taste, $16 \%$ of respondents answered that it was according to the manufacturer's claim, and only $3 \%$ of respondents answered - in some other way (purchase from the established manufacturer, recommendation, geographical origin, etc.). The idea that the state should regulate by law the standardized labelling, which guarantees the organic products origin was most widely differentiated by analysing the obtained answers (94.5\%). One percentage of respondents thinks that it is not necessary, while $4.5 \%$ of surveyed respondents have no opinion on this.

Organic products are the products manufactured in a strictly controlled production method, legally regulated and called the organic production. The organic products on the market are recognized by a legally regulated mark. Consumers, by purchasing the products with the "organic"mark, can be sure that at least $95 \%$ of this product is of the organic origin, and that a product complies with regulations of the inspection, that it is packed in a biodegradable packaging, code and body that carried out the inspection. The certified organic product must be labelled by the mark "organic product"(Vlahovic and associates, 2011). The answers show that the state should more seriously be involved in legal regulations regarding the guarantee of organic products origin. State institutions are the carrier of trust and the only serious guarantor of food's organic origin. In every moment, the consumer has to be sure that only products of authorised manufacturers are on the market, and these products are under constant supervision of the authorised institutions, which check the quality that is completely harmonized with the international standards.

The first law on the organic production in our country was passed in 2000 , and the second was passed in 2006, while the third law on the organic production was come into effect on $1^{\text {st }}$ January 2011, and was adopted by the Serbian Parliament on $5^{\text {th }}$ May 2010 (Official Gazette no. 30/2010). This law and by-laws regulate in detail all issues regarding the organic production methods, control and certification, processing, storing, transport, turnover and labelling the organic products.

Respecting the standard and legally regulated conditions of production, processing, storing, turnover, labelling of organic products etc. isunder the expert supervision of the state administration authorities. The organic product control system in Serbia has been established in the tradition of the control system that is regulated by EU regulations, i.e. the EC Council Regulation no. 834/2007 and the Commission Regulation (EC) no. 889/2008. 
The law aims to:

- Get products with confirmed manufacturing procedure,

- Sustainable socio-economic rural development,

- Consumer protection, putting a label that clearly indicates the way and methods for obtaining organic products,

- Protection of natural resources from pollution,

- Long-term preservation and increase in soil fertility,

- Preservation of biodiversity etc.

The question about the organic products flavour was put in the form of a multiple answer. The aim was to perceive the consumers' attitudes on the organic products flavour. The survey showed that the respondents' opinions divided and 52.5\% of respondents have no attitude on whether the organic products were tastierin regard to the conventional ones. If $30 \%$ of the surveyed respondents have declared themselves as those who don't buy organic products, then it is understandable a high percentage of the survey participants who don't have any attitude on this. Studies that were carried out related to the organic and conventional food comparison were based on three essential fields: nutritional value, sensory quality and food safety. According to Boum and Prescott (2002), there are no strong evidences that the organic and conventional food differs in concentration of different nutrients, except in the content of nitrates. According to these same authors, the research that points out to the existence of differences between the organic and conventional fruits and vegetables is inconsistent. Numerous authors who were engaged with this issue (Williams 2002, Magkos and associates, 2006, Brandt and Molgaard, 2001) concluded that there were no sufficient evidences on the higher share of nutrients in the organic manufactured food in regard to the traditionally manufactured food.

On the following question, whether they buy or are ready to buy the organic products, $83.5 \%$ of respondents answered with "yes"or are ready to buy the organic products, and they are aware that these products have an effect on their health, as personally as well as on their family health. They stated the next reasons for the quality of organic products: higher nutritional value, more minerals, vitamins and other useful ingredients. Only 16.5\% of respondents gave a negative answer to this question, and give as the most common reasons: high price of organic products, current financial situation, distrust habits, insufficient information, etc. Around $70 \%$ of respondents gave a positive answer to the question if they are willing to pay more for the product that is surely of the organic origin. At the same time, 15\% of respondents are not ready to pay more, and $15 \%$ of respondents are not sure if they are ready to pay more for the organic products. According to the previous research of this problem, Vlahovic and associates (2010) concluded that $55 \%$ of respondents are ready to pay a higher price to the organic products, and $23 \%$ of them are not ready to pay a higher price. $22 \%$ of respondents are not sure if they are willing to pay more (don't have a clear view on this issue). In the conducted survey, we can notice the increase in a number of respondents who are willing to pay a higher price for these products in regard to the mentioned previous research. According 
to the research of Kovacic and associates (2009) related to the city of Zagreb, more than three fourth of respondents are ready to pay a higher price for these products in regard to other products, while one fourth of respondents is not ready or are not sure if they are ready to pay for it a higher price. It is far more in regard to the conducted survey in the Republic of Serbia. In accordance to the KarapandzinJelena (2003) survey results, which was exclusively related to students of the Faculty of Agriculture in Novi Sad, most of respondents were answered positively (60\%), and on the other side was $40 \%$ who were not willing to pay more for the organic product.

In order to test the readiness of consumers to pay more for the organic products, the question was put with the possibility to choose an answer. According to the obtained answers can be concluded that $33.5 \%$ of respondents are ready to pay $10 \%$ more for an organic product, $6 \%$ of respondents are ready to pay $11 \%-20 \%$ more, and $23.5 \%$ of respondents consider real to pay $21 \%-30 \%$ more, $5.5 \%$ of respondents are ready to pay $31 \%-50 \%$ more, while $12 \%$ of respondents are ready to pay more than $50 \%$ higher price in regard to the conventional products.Many researches have shown that a higher price of organic products is the main obstacle why consumers rather opt for the conventional food (Klockner, 2012).

Chart 6. What is the willingness of the respondents to pay more for an organic product $(\%)$

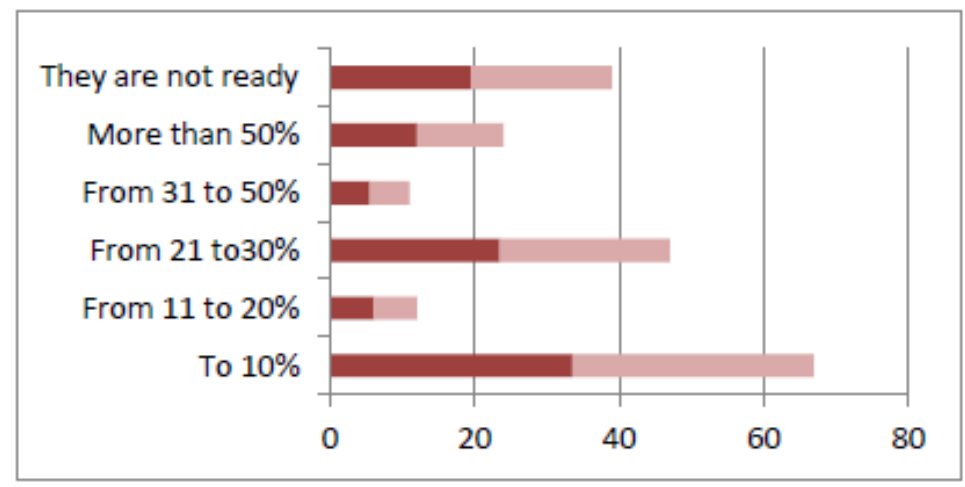

Source: Authors's research

There is a need for the better economic propaganda of organic products - the question was put aimed to determine the attitude of respondents if the better economic propaganda for organic products was necessary. There was concluded, by analysing answers, that most of respondents $(79 \%)$ was considering the necessity of better economic propaganda related to products of the organic origin. Only 4\% of respondents considered that the economic propaganda was at the appropriate level, while $17 \%$ of respondents didn't have a defined attitude on the organic products' economic propaganda. The research results of Vlahovic and associates (2011) showed that there was a clear need for intensifying the promotional activities ( $61 \%$ of respondents), aimed to increase the demand for organic products, while $10 \%$ of respondents had opposite views. Accordingly, the promotional activities of companies should become prominent aiming to have more influence on 
the decision of purchasers. When it comes to the most adequate way of informing the potential consumers on organic products, the respondents were mostly (79\%) took side of the media propaganda via television, social networks, etc. Promotion at the point of sale is of the highest importance for $17 \%$ of respondents, and various catalogues and booklets for $4 \%$ of respondents. The answers to this question should specify in which direction the promotional activities should be drafted, i.e. should point out to the best and the most efficient media and instrument in the promotional activities.

The last question in the survey was put if the organic production is important for the environment protection and that is why organic products should be bought and consumed, none of respondents answered that they absolutely disagreed, 4\% of respondents disagreed, and $31 \%$ of the survey respondents agreed partially. $35.5 \%$ of respondents agreed, and $29.5 \%$ of respondents agreed completely that the organic production was important for the environment protection. Whether the organic agricultural products are significant for the consumers' health, we did obtain the following answers: $3 \%$ of respondents didn't agree, $21.5 \%$ of respondents did agree partially, 34\% did agree, and $41.5 \%$ of respondents did agree completely that organic agricultural products were important for the consumers' health, so this was the reason for their consumption.

In accordance to Hallam (2002) research, the motives for purchasing the organic agriculture products in Great Britain were:improvement of personal health (36\%), better taste $(31 \%)$, "natural"origin of food $(25 \%)$, avoiding genetic modifications (12\%) and the environmental protection (5\% of respondents). According to Vlahovic and Puskaric (2013), numerous studies were engaged in comparing nutrition and health values of organic and conventional food. Some studies show that food manufactured organically doesn't have a higher nutritional value than the conventional one, while other studies show that organic food is superior, especially in respect of a greater content of antioxidants.

\section{Conclusion}

There can be concluded the following based on the obtained research results, and based on the survey on the consumption of organic agriculture products:

All 100\% of the respondents have heard about the organic food term, while $70 \%$ of them have purchased organic products $(23.5 \%$ once a week, $23.5 \%$ of respondents always buy a specific type of organic products, $15 \%$ of respondents buy it once a month and $8 \%$ of respondents buy it once in three months). The most common reasons for buying the organic products, for $50 \%$ of the respondents were that the organic products are healthier for diet in regard to the conventional products, $38.5 \%$ of the respondents were stated as the reason the better quality of organic products. The most of the respondents purchase all organic products depending of needs $(60.5 \%)$, only vegetables $16.5 \%$ and fruits $12 \%$. The supply of markets with organic products is not sufficient, as $68.5 \%$ of the respondents stated, while $90.5 \%$ of the respondents stated that population in Serbian enclaves is not sufficiently informed on the significance of food manufactured in the 
organic production system. There is inevitable more significant education of consumers regarding the organic production in order to be better informed and to increase demand. The most of the respondents (79\%) do not have confidence in labelling of organic food, and that they really guarantee the organic origin of these products, while $94.5 \%$ of the respondents think that a state should legally regulate standardized labelling, which guarantees the organic products origin.

Only $70 \%$ of the respondents are ready to pay higher price for organic products. The most of the respondents $(33.5 \%)$ is ready to pay $10 \%$ more for organic products, $29.5 \%$ of respondents are ready to pay $10-30 \%$ more money for purchasing organic products, while $17.5 \%$ of respondents are ready to pay more than $30 \%$ for them. $75.5 \%$ of respondents agreed that food manufactured in organic way is very important for consumers' health and therefore it should be purchased and consumed.This seems very encouraging, because consumers care about their health, and this should also motivate the organic food manufacturers to increase volume and range of their products. The amount of income significantly limits the readiness of respondents to set aside more money for purchasing the organic agricultural products.

The most of the respondents purchase organic food in super markets $(21.5 \%)$, green markets (21\%), small shops in the vicinity (20.5\%), in health food stores $(10 \%)$, directly from the manufacturer $(16 \%)$, and in some other way $(11 \%)$. Retail chains of general type have the highest share in supply (31\%) in the structure of total sale of organic agricultural-food products in the European Union. In the USA, one third of consumers purchase in specialized health food stores. Our survey shows an evident decrease in the significance of specialized stores of so called organic food.

Results show under developed awareness of consumers on organic food. The organic food market is still very modest. It is necessary to enlarge the range of products in the organic production and food industry, and have continuous supply and develop an adequate marketing. It is possible to raise consumption at the higher level by good information and education of consumers.

\section{Literature}

1. Aarset, B., Beckmann, S., Bigne, E., Beveridge, M., Bjorndal, T., Bunting, J., McDonagh, P., Mariojouls, C., Muir, J., Prothero, A., Reisch, L., Smith, A., Tveteras, R., Young, J. (2004): The European consumers " understanding and perceptions of the ,organic “ food regime The case of aquaculture " British Food Journal Vol. 106, No. 2.

2. Bourn, D., Prescott, J. (2002): A Comparison of the Nutritional Value, Sensory Qualities, and Food Safety of Orrganically and Conventionally Produced Foods.Critical Reviews in Food Science and Nutrition Vol.42 I.1.

3. Brandt, K., Molgaard, P. J. (2001): Organic agriculture: does it enhance or reduce the nutritional value of plant foods?, Journal of the Science of Food and Agriculture Vol. 81, No. 9.

4. Briz, T., Al-Hajj, M. (2004.): Consumer"s attitude regarding organic products: 
Marketing Trends for Organic Food in the 21 st Century, Series on Computers, and Operations Research, Vol.3, World Scientifi c Publishing Co.,Pte. Ltd.

5. Chakrabarti, S., Baisya, R.K, (2007): Purchase Motivations and Attitudes of Organic Food Buyers, Decision, Vol. 34, No. 1.

6. Chambers, S., Lobb, A., Butler L.T., Traill, B.W. (2008): The influence of age and gender on food choice: a focus group exploration, International Journal of Consumer Studies, Vol.32, No.4.

7. Eves, A., Lumbers, M., Morgan, J. (2004): Factors influencing consumption of organic food, Marketing Trends for Organic Food in the 21st Century, Series on Computers and Operations Research, Vol.3, World Scientific Publishing Co., Pte. Ltd.

8. Golijan, J., Popović, A. (2016): Basic characteristics of the organic agriculture market, Fifth International Conference Competitiveness Of Agro-Food And Environmental Economy, Bucharest.

9. Hallam, D. (2002): The organic market on EOCD Countries: Past Growth, current status and Future Potential, OECD Workshop on Organic Agriculture, Washington D.C., USA

10. Klockner, A. C. (2012): Should I Buy Organic Food? A Psychological Perspective on Purchase Decisions Organic Food and Agriculture, Nwe Trends and Developments in the Social Sciences.

11. Kovačić, D.,Mesić, Ž., Pavićević, A. (2009.): Analiza potražnje ekoloških proizvoda na zagrebačkom tržištu, available at: http://s-a.agr.hr/pdf/2009/sa2009_p0218.pdf

12. Lappalainem, R., Saba, A., Holm, L., Mykkanen, H., Gibney, M.J., Moles, A. (1997): Difficulties in Trying to Eat Healthier: descriptive analysis of perceived barriers for healthy eating, European Journal of Clinical Nutrition, Vol. 51 (Suppl.2).

13. Meredith, S.,Willer, H. (2016):Organic in Europe-prospects and developments.

14. Ministarstvo poljoprivrede i zaštite životne sredine, 2016. http://www.dnrl.minpolj. gov.rs/ accessed on: 05.08.2016.

15. Radojičić, A. (2013.): Istraživanje stavova potrošača o potrošnji organske hrane u Srbiji, magistraska teza, Poljoprivredni fakultet, Novi Sad.

16. Renko, S., Bošnjak, K., (2009): Aktuelno stanje i perspektive budućeg razvoja tržišta ekološke hrane u Hrvatskoj, Ekonomski pregled, Vol. 60,No. 7-8, Zagreb.

17. Vehapi, S. (2015):Istraživanje motiva potrošača koji utiču na kupovinu organske hrane u Srbiji, Ekonomske teme, Vol. 53, No. 1, pp. 105-121.

18. Vlahović B., Radojević, V., Živanić, I., (2011): Istraživanje stavova potrošača o potrošnji organske hrane u Srbiji, Ekonomika poljoprivrede, Vol. 58, No. 3.

19. Vlahović, B., Puškarić, A. (2013): Organska poljoprivreda - šansa za agrobiznis, Grad Novi Sad, uprava za privredu Novi Sad.

20. Vlahović B., Tomić, D., Popović, V. (2010): Stanje i perspektive potrošnje proizvoda organske poljoprivrede, Zbornik radova, Četvrti forum o organskoj proizvodnji, Selenča.

21. Willer, H., Lernoud, J. (Eds) (2016): The World of Organic Agriculture. Statistics and Emerging Trends 2016, Research Institute of Organic Agriculture (FIBL), Frick, and IFOAM Organics International, Bonn. 
22. Williams, M.C.(2002): Nutritional quality of organic food: shades of grey or shades of green?, Proceedings of the Nutrition Society, Vol. 61.

23. Zakon o organskoj proizvodnji 2010 (Službeni glasnik RS broj 30-10), Pravilnik o kontroli i sertifikaciji u organskoj proizvidnji i metodama organske proizvodnje " Ministarstvo poljoprivrede, trgovine, šumarstva i vodoprivrede, Službeni glasnik Republike Srbije, no. 4811

\title{
ISTRAŽIVANJE STAVOVA POTROŠAČA O ORGANSKOJ HRANI U SRPSKIM ENKLAVAMA NA KOSOVU
}

\author{
Goran Maksimovićc ${ }^{4}$, Božidar Miloševič ${ }^{5}$, Radomir Jovanovićc ${ }^{6}$
}

\section{Rezime}

Organska proizvodnja u srpskim enklavama na Kosovu ima veliki potencijal na osnovu ekstenzivne proizvodnje većim delom u brdskoplaninskim predelima sa bogatim $i$ prikladnim ambijntom za organsku proizvodnju lekovitog bilja, voća, vina,meda itd, ali je još uvek u ranoj fazi razvoja. Proizvodnjom i plasiranjem organskih proizvoda na lokalnim tržištima enklava može se ostvariti višak prihoda a time i ekonomska osnova za održiv razvoj mulifunkcionalnih poljoprivrednih gazdinstava u srpskim enklavama. U radu autori istražuju stavove potrošača o kupovini i potrošnji organske hrane na Kosovu. Empirisko istraživanje je vršeno na prostom uzorku od 300 ispitanika tehnikom ličnog komuniciranja uz primenu anketnog upitnika kao instrumenta metode ispitivanja. Područje ispitivanja su gradovi: Severna Kosovska Mitrovica, Leposavić, Zubin Potok i Gračanica. Cilj istraživanja jeste da se na bazi definisane ankete sagledaju osnovna obeležja potražnje i potrošnje organskih poljoprivrednih i prehranbenih proizvoda da se dođe do saznanja o preferencijama, motivima, stavovima potrošača za kupovinu organsih proizvoda. Nakon analize urađene ankete došli smo do saznanja da tržište organske hrane u srpskim enklavama na Kosovu još uvek nije u dovoljnoj meri razvijeno. Neophodno je proširiti asortiman proizvoda organske poljoprivrede $i$ neophodna je kontinuirana ponuda, veći marketing i bolja informisanost i edukacija potrošača da bi se potroš nja podigla na viši nivo.

Ključne reči: organska poljoprivreda, potrošnja organske hrane.

\footnotetext{
4 Vanredni profesor, drGoran Maksimović, Univerzitetu Prištini, Poljoprivredni fakultet, Kopaonička ulica bb, 38219 Lešak, Srbija, Telefon: +381 63419 757, E-mail: goran.maksimovic@pr.ac.rs

5 Redovni profesor, dr Božidar Milošević, Univerzitet u Prištini, Poljoprivredni fakultet, Kopaonička ulica bb, 38219 Lešak, Srbija, Telefon: +381 64150 5273, E-mail: bozidar.milosevic@pr.ac.rs

6 Dr Radomir Jovanović, Univerzitet u Prištini, Poljoprivredni fakultet, Kopaonička ulica bb, 38219 Lešak, Srbija, Telefon: +381 65561 3940, E-mail: radomir.jovanovic@pr.ac.rs
}

EP 2017 (64) 3 (987-1001) 